\title{
Concept of Building of Environmental Awareness Character Through Integrated Organic Farming Learning: A Study in Sekolah Alam Cikeas, Gunung Putri, Bogor
}

\author{
Kholidin $^{1}$, Dwi Nowo Martono ${ }^{2}$, Tri Edhi Budhi Soesilo ${ }^{3}, \mathrm{Nadiroh}^{4}$ \\ \{kalfaqih@yahoo.com¹,nowo2003@yahoo.com ${ }^{2}$, soesilo@indo.net.id ${ }^{3}$, nadiroh@unj.ac.id $\left.{ }^{4}\right\}$ \\ Universitas Indonesia, Indonesia ${ }^{1,2,3,4}$
}

\begin{abstract}
Some issues of sustainable development are land conversion and forest destruction with total emissions reaching 2.53 billion tons of $\mathrm{CO}_{2}$; and the activity and use of agricultural energy by machine with emissions reaching 451 million tons of $\mathrm{CO}_{2}$. Human behaviours cause them. Some of human actions which destructive to environment are damaging crops, cut down trees, wasteful use of water, damaging the soil with littering. These characters must convert to the role which concerned about the environment. The problem of the study is the students in Sekolah Alam Cikeas do not seem to care about the environment, even though there is an integration of organic farming learning. The purpose of this study is to make a concept of a combination of natural farming learning for the character building of environmental awareness. This study uses a systematic method of literature review, which is a literature review that identifies, evaluates, and interprets all findings on a research topic, to answer research questions. Data sources are national and international scientific journals starting from 2000 to 2018 . The result is a concept of building environmental awareness, namely habituation to appear in love to plant crops, the role of teachers to combine matter for the learning outcomes, value transfer of ecological care by saving the use of fertilizers, water, and do not litter. The conclusion of this study is the concept of environmental care character on the integration of farming learning could build through habituation, the combination of knowledge, and value transfer of ecological awareness.
\end{abstract}

Keywords: Environmental Awareness Character, Organic Farming Learning, Character Building.

\section{Introduction}

Indonesia increased waste production of 2 million tons, which is 65 million tons in 2016 to 67 million tons in 2017. Furthermore, it also reports that the land conversion and forest destruction by the number of emissions to reach 2.53 billion tons of $\mathrm{CO}_{2}$; and agricultural activity and energy consumption with emissions of 451 million tons of $\mathrm{CO}_{2}$ [1]. The situation is the result of human behavior, which is damaging to the environment. One of the environmentally destructive social behaviors is damaging crops, cutting down trees, even without fell guilt throw trash on vacant land.

These conditions need to alleviate by building the character of environmental care. The attitude of keeping the natural surroundings without damaging the plants are hard to change 
because it requires behavioral habituation [2]. Besides, by conducting habituation environmental management activities learners will build the nature of protecting the environment [3][4]. Therefore, education develops character and civilization of the nation's dignity in the context of the intellectual life of the country. It's aimed at developing students' potentials to become a man of faith and fear of God Almighty, noble, healthy, knowledgeable, skilled, creative, independent, and become citizens of a democratic and responsible [5].

Education is one of the efforts to create the character of environmental awareness, through the integration of organic farming learning. Some of studies show that the integration natural farming learning is able to change behavior or character of farmer. The study has a characteristic, it is able to build the characters of protecting the environment and increase knowledge in students through agricultural activities [6]. Furthermore, farmer behavior which environmentally friendly farming is able to change their life to healthier [7][8]. In addition to affecting behavior, organic agriculture also affects the environment. Based on the research, the application of organic farming can improve or enhance soil fertility and free pesticide vegetable [9]. Furthermore, organics crop management can significantly improve soil structure [10].

It is prompt the authors to conduct this research. Also, there are problems at the Sekolah Alam Cikeas; namely, some students do not seem the character of environmental stewardship when the integration organic farming learning. The purpose of this research is to create a concept to build a generation that cares about the environment through the combination of organic farming learning. The benefit is to contribute ideas in the form of the integration organic farming learning concept to build characters who care about the environment and as a reference in further research to relate to the building of characters who care about the environment. The question in this study is how the concept of the integration organic farming learning to build the character of environmental awareness?

\section{Research Method}

This study uses a systematic method of literature review, which is a literature review that identifies, evaluates, and interprets all findings on a research topic, to answer research questions. Data sources are national and international scientific journals starting from 2000 to 2018. Then the authors analyse with equations, provide views, compare, and summarize. The results of the literature review are present directly into the sub-chapter habituation, integration of learning, and the transfer of environmental values.

\section{Result and Discussion}

The discussion in this paper consists of habituation, the integration of learning, and the value transfer of environmental awareness.

\subsection{Habituation}

Building the character of the human especially students is not easy. It requires intervention from the human thought. It is called habituation. The activity if done on an ongoing basis will form the desired character. Activities carried out on an ongoing basis will 
form the desired character. The process of habituation to care for the environment will form the character of protecting plants, can dispose of trash in its place, save water, and use natural materials to reduce environmental risks.

Habituation is the process of creating a situation (persistence life situation) that allows students in everywhere to get used to behaving in accordance with values and become the character itself, because it is internalize and personify through an intervention process [11]. Then [3], states that habituation that takes place continuously and is embedded in the human subconscious mind (subconscious) will have an action in everyday life. Furthermore, [12] states that habituation activities generate awareness about environmentally friendly environment.

The process of habituation and awareness is able to apply to a subject matter. Research conducted by [12], states that fostering environmental awareness in curricular learners through civic education has an essential role in cultivating moral virtues against preservation environment. The process of habituating moral values is the integration of each learning material (direct integration) with the school environment (physical and non-physical elements). Besides that, the process is the integration of the moral values of habituation with other activities, such as routine, spontaneous activities, exemplary activities, programmed activities [13].

Habituation in environmental education will work optimally with the support and commitment of all members of the school, which is exemplary teachers, staff, principals, and school committees [14][15][16][17]. School community apply the habit of implementing character education continuously. This habit will create the character of caring for the environment with a loving nature and protecting the environment [18][19][20][21]. Also, habituation can improve learning outcomes in environmental character education [22].

Activities, regulations, student programs, lesson integration, and teaching aids can build character holistically.

\subsection{Integration of Learning}

Character education forms the desired values. Learning about integrated organic farming can be carried out through the planting, watering, fertilizing, pest and disease control, harvest and post-harvest. At planting activities are learning to learn, which gives a lot of benefits for the environment, as a patron, and the identification of plants. The activities of watering, fertilizing, and pest and disease control, children can recognize the name and type of vegetable, leaf shape, how plants to get food.

On learning materials to control pests and diseases, the students can study plant protection, the students also get lessons on types of leaf-eating insects, such as the type of mouth, kind of wing, and the identification of other insects. Also to cognitive enhancement, the integration organic farming learning can increase self-contained character. Based on research conducted by [23], that organic farming learning creates independent character, namely discipline and conscientiousness, independence and hard work, religious, togetherness, attention, compassion, humility, respect, courtesy, courtesy, responsibility answer, honesty, and sincerity. The learning uses habituation, exemplary, and socialization methods [24].

The activities and behavior of students have a role in creating the character of environmental care. The research results [25], states that there is a positive correlation between the results of learning about the environment with the student's behavior towards the environment. Then [26], states that high school students who participated in the environment have an average score of attitude to the environment tend towards the positive and the average 
score of concern for the environment is greater than students who do not follow it. Furthermore, [27][28], states that quality of and implementation of inquiry learning and learning outcomes affect the establishment of environmental care attitude. The higher the quality of learning the students will be more positive attitude and the better the learning outcomes, students will be more positive attitude as well.

One of the schools that apply the learning integration is Sekolah Alam Cikeas (SAC). The school is applying the learning by integrating every five pillars of learning materials with the Sekolah Alam Cikeas, namely 1). Good morals (the way humans are subject to the Creator), 2). Scientific logic (the way the universe is subject to the Creator), 3). Leadership (how people become leaders on earth), 4). Nationality (how to love the nation and state), and 5). Entrepreneurship (how to seek fortune kosher). One example of the integration of learning is presented in Figure 1.

In addition, the SAC also has the concept of education, namely: quality teachers (as facilitators and role models in the process of establishing the morals of children), good books (as a gateway to science), outbound (as a means of creating leadership), and the nature (as a laboratory without limit). The concept aims apart from the cognitive and psychomotor student, also create the behavior of students (affective).

Sekolah Alam Cikeas learning activities inside and outside. The school must have goals relate to the vision and mission of the school premises. These activities have a purpose, which is to build awareness of environmental concerns, and perform simple actions in the school environment and the family environment. Sekolah Alam Cikeas also involve parents and the community of learners in a learning program that purpose so that parents and the surrounding community also feel the presence of the Sekolah Alam Cikeas.



Fig. 1. Integration of environmental care learning on integrated organic farming learning (by author, 2019).

\subsection{Transfer Value of Environmental Awareness}

Character education is not just getting children to behave well, more than that, namely forming thoughts, character, and good behavior. Efforts are made in transfer the values of 
character care about the environment, namely: learning by doing; system team (patrol system); outdoor activities; recreation and fill the time with positive activities [29]. The process of creating of the character shows a close link between thoughts, feelings and actions. From the region creates a way of thinking and sense of physical area forms the way it behaves. This way of thinking into a vision, how to feel mentally and how to behave to character [30].

The efforts made to raise awareness of the environment is with the recommendation, make the rules and the program that is routinely managed and sustainable, environmental education outreach, neighborhood-based school programs, and the development of cultural awareness [31][32][33]. Other efforts, as was done by Prasetiyo and Suyanto [34], is researching the behavior in society, namely the creates of citizen participation in environmental awareness activities include: regular voluntary work; planting and care of plants; sorting of waste; cutting the trash; use aerobic composter; and composting.

Learning tools can implement the values of environmental care. Global warming props can determine the level of character care about the environment [35]. Then Khusniati [36], using the application of science learning model based on local wisdom is able to grow the value of conservation character students. Next, Ariyani and Wangid [37]; Soeprijanto and G. Femalia [38], states that examples of creative teaching materials are the integration of themes with environmental evaluation models of character care and responsibility.

Of the three literature review topics, the concept of building a character of caring for the environment can be done by connecting the three basic concepts as shown in Figure 2.

Concept of Character Building of Environmental Awareness

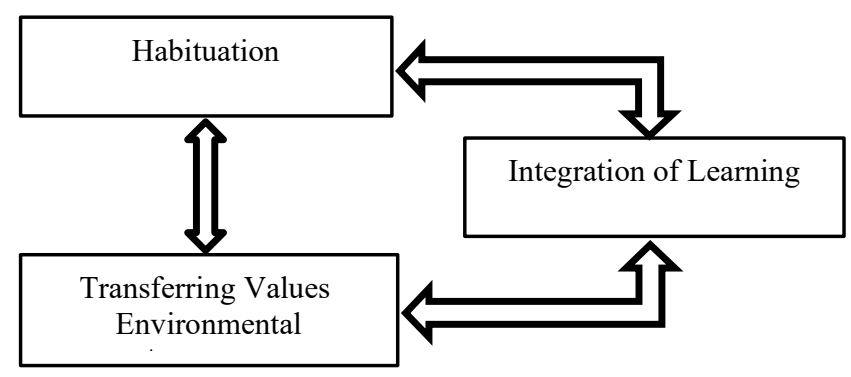

Fig. 2. The concept building of environmental concern character in the integration of organic farming learning (by author, 2019).

Based on Figure 2, we can find out that an important component in building the character of caring for the environment is habituation, the integration of learning, and the transferring of environmental values. The components are interrelated and complementary. Therefore, needs collaboration from each component so that the process can run optimally and will produce students who have environment awareness character. Habituation will work optimally with the support and strong commitment of all school members to do environmental awareness. Learning do in an integration manner will make students more quickly understand about what is taught and can develop students' mindset that is more holistic. The transfer of value of environmental awareness carried out with loving, patience, and commitment of the teacher to transfer it, makes the students easily accept the value given. 


\section{Conclusion}

The conclusion of this research is building the character of environmental awareness in integrated organic farming learning can create through consistent habituation, integration of learning related to the environment, and the transfer of values that care about the environment. Characters of environmental care that can be created are to love plants, save the water, do not litter, clean the air, and to keep soil fertility. The recommendation for further research is integrated organic farming learning can do with urban farming to save the land in urban areas because not all the school have spacious land for integrated organic farming learning.

\section{References}

[1] D. Tjumano, "Kerusakan Lingkungan Hidup di Indonesia," 2018. .

[2] A. Susanto, "Proses Habituasi Nilai Disiplin Pada Anak Usia Dini Dalam Kerangka Pembentukan Karakter Bangsa," Sosio Reli. J. Kaji. Pendidik. Umum, vol. 15, no. 1, 2017.

[3] H. Jayawardana, "Pendidikan Karakter Peduli Lingkungan Sejak Dini sebagai Upaya Mitigasi Bencana Ekologis," in Symbion (Symposium on Biology Education), 2016, pp. 49-64.

[4] M. Mukani and T. Sumarsono, "Pendidikan Karakter Peduli Lingkungan Berbasis Adiwiyata pada Mata Pelajaran Fiqih di MTsN Tambakberas Jombang," J. Pendidik. Agama Islam (Journal Islam. Educ. Stud., vol. 5, no. 2, pp. 181-200, 2017.

[5] Government of Indonesia, National Education System. 2003.

[6] I. P. Nurhidayati, A. Solichah, and B. A. Djuhari, "Pertanian organik. suatu kajian sistem pertanian terpadu dan berkelanjutan," Progr. Stud. Agroteknologi Jur. Budid. Pertan. Fak. Pertan. Univ. Islam Malang, Malang, 2008.

[7] T. Novita, "Pemberdayaan Masyarakat Melalui Pengembangan Pertanian Organik Berbasis Trikolimtan di Kota Sungai Penuh Provinsi Jambi,” J. Pengabdi. Pada Masy., 2011.

[8] S. Srinieng and G. B. Thapa, "Consumers' Perception of Environmental and Health Benefits, and Consumption of Organic Vegetables in Bangkok," Agric. Food Econ., vol. 6, no. 1, p. 5, 2018.

[9] F. N. Simanjuntak, "Penerapan pertanian organik untuk mengendalikan kualitas kesuburan tanah dan menghasilkan produk pangan bebas pestisida (Studi kasus pertanian organik Bina Sarana Bhakti Cisarua, Bogor)," Tesis Sekol. Ilmu Lingkungan, Univ. Indones., 2006.

[10] V. L. Puerta, E. I. P. Pereira, R. Wittwer, M. Van Der Heijden, and J. Six, "Improvement of soil structure through organic crop management, conservation tillage and grass-clover ley," Soil Tillage Res., vol. 180, pp. 1-9, 2018.

[11] M. Samani, "Hariyanto, Pendidikan Karakter: Konsep dan Model," Bandung PT Remaja Rosdakasrya, $n d, 2011$.

[12] M. Saputra, "Pembinaan Kesadaran Lingkungan Melalui Habituasi Berbasis Media Sosial Guna Menumbuhkan Kebajikan Moral Terhadap Pelestarian Lingkungan," J. Moral Kemasyarakatan, vol. 2, no. 1, pp. 14-29, 2017.

[13] D. Gularso and K. A. Firoini, "Pendidikan Karakter Melalui Program Pembiasaan Di SD Islam Terpadu Insan Utama Bantul Yogyakarta," TRIHAYU J. Pendidik. Ke-SD-an, vol. 2, no. 2, 2016.

[14] N. Nurjani and M. Mundilarno, "Pembentukan karakter melalui manajemen pembiasaan di sekolah dasar islam terpadu Ihsanul Fikri Kota Magelang," Wiyata Dharma J. Penelit. dan Eval. Pendidik., vol. 4, no. 1, pp. 47-53, 2016.

[15] M. Saputra, "Pengaruh Habituasi, Media Sosial dan Pembelajaran Pendidikan Kewarganegaraan Terhadap Kesadaran Lingkungan Siswa SMA: Studi Survei pada SMA Negeri Se-Kota Bandung." Universitas Pendidikan Indonesia, 2015.

[16] A. Rachman, "A Study on Character Building Based on Habituation to Form Students' 
Character," in 5th SEA-DR (South East Asia Development Research) International Conference 2017 (SEADRIC 2017), 2017.

[17] Z. Zaenuri, S. Sudarmin, Y. Utomo, and E. Juul, "Habituation model of implementing environmental education in elementary school," J. Pendidik. IPA Indones., vol. 6, no. 2, pp. 206-212, 2017.

[18] T. Z. Mutakin, "Penerapan Teori Pembiasaan Dalam Pembentukan Karakter Religi Siswa Di Tingkat Sekolah Dasar," Edutech, vol. 13, no. 3, pp. 361-373, 2014.

[19] D. Saripudin and K. Komalasari, "Living values education in school's habituation program and its effect on student's character development," New Educ. Rev., vol. 39, no. 1, pp. 51-62, 2015.

[20] S. Lisnawati, "The Habituation of Behavior as Students' Character Reinforcement in Global Era,” J. Pendidik. Islam UIN Sunan Gunung Djati, vol. 2, no. 3, pp. 413-428, 2016.

[21] E. H. Mulyana, H. Hodidjah, and L. S. Ramadhan, "Pengembangan Rumah Sampah Berbasis Sekolah (RSBS) untuk Pembiasaan Karakter Peduli Lingkungan Anak Usia Dini di RA AlIkhlas Kecamatan Pagerageung Kabupaten Tasikmalaya,” J. PAUD AGAPEDIA, vol. 1, no. 1, pp. 13-19.

[22] U. Hadi Wahyu Daryono, "Pengaruh Metode Pembelajaran Modeling, Penguatan, dan Pembiasaan Terhadap Hasil Pembelajaran Pendidikan Karakter Peduli Lingkungan dalam Pendidikan Jasmani Olahraga dan KesehataN,” J. Pendidik. Olahraga dan Kesehat., vol. 4, no. 2, 2017.

[23] M. Budiyanto and I. Machali, "Pembentukan Karakter Mandiri Melalui Pendidikan Agriculture Di Pondok Pesantren Islamic Studies Center Aswaja Lintang Songo Piyungan Bantul Yogyakarta," J. Pendidik. Karakter, no. 2, 2014.

[24] A. Rifa'i, S. D. W. Prajanti, and M. Y. Alimi, "Pembentukan Karakter Nasionalisme melalui Pembelajaran Pendidikan Aswaja pada Siswa Madrasah Aliyah Al Asror Semarang," J. Educ. Soc. Stud., vol. 6, no. 1, pp. 7-19, 2017.

[25] D. Safitri, "Hasil belajar dan sikap dengan perilaku mahasiswa pada lingkungan hidup di Jakarta Selatan.” Pasca Sarjana-UI, 2000.

[26] R. Dewi, "Pengukuran pengetahuan sikap dan kepedulian siswa SMA pada lingkungan hidup: Studi ksus: Perbedaan pestasi blajar antara siswa SMA yang mengikuti Pramuka dengan siswa SMA yang tidak mengikuti Pramuka pada tiga SMA di Kota Bekasi.” Pasca Sarjana-UI, 2007.

[27] M. Taufiq, N. R. Dewi, and A. Widiyatmoko, "Pengembangan media pembelajaran ipa terpadu berkarakter peduli lingkungan tema 'konservasi' berpendekatan science-edutainment," $J$. Pendidik. IPA Indones., vol. 3, no. 2, p. 122575, 2014.

[28] H. M. Zainuddin, H. Mustofa, and D. S. Hakam, "Membentuk Karakter Peduli Lingkungan dengan Model Pembelajaran Inkuiri," Mimb. J. Sos. dan Pembang., vol. 30, no. 1, pp. 11-17, 2014.

[29] A. N. Hikmah, "Upaya Pembentukan Karakter Siswa Melalui Kegiatan Ekstra Kurikuler Pramuka di SDIT Salsabila 2 Klaseman Sinduharjo Ngaglik Sleman," Al-Bidayah J. Pendidik. Dasar Islam, vol. 7, no. 1, 2015.

[30] Amilda, "Pembentukan karakter anak usia dini melalui pembiasaan," Raudhatul Athfal J. Pendidik. Islam Anak Usia Dini, vol. 1, no. 2, 2017.

[31] W. Ramdani, "Kesadaran Santri Terhadap Kesehatan Lingkungan: Studi Kasus Pesantren Nurul Hidayah Leuwilang Bogor." Tesis, 2008.

[32] I. Rahmawati and I. Suwanda, "Upaya Pembentukan Perilaku Peduli Lingkungan Siswa Melalui Sekolah Adiwiyata di SMP Negeri 28 Surabaya," Kaji. Moral dan Kewarganegaraan, vol. 1, no. 3, pp. 71-88, 2015.

[33] J. La Fua, R. U. Nurlila, and I. S. Wekke, "Strategy of Islamic Education in Developing Character Building of Environmental Students in Indonesia," in IOP Conference Series: Earth and Environmental Science, 2018, vol. 175, no. 1, p. 12149.

[34] W. H. Prasetiyo and T. Suyanto, "Strategi pendidikan karakter peduli lingkungan melalui program kampung hijau di Kampung Margorukun Surabaya," Kaji. Moral dan Kewarganegaraan, vol. 2, no. 1, pp. 302-316, 2013.

[35] A. M. Sari and A. Widiyatmoko, "Pengembangan Alat Peraga Pemanasan Global Berbahan 
Bekas Pakai Untuk Menanamkan Karakter Peduli Lingkungan," Unnes Sci. Educ. J., vol. 3, no. 3, 2014.

[36] M. Khusniati, "Model pembelajaran sains berbasis kearifan lokal dalam menumbuhkan karakter konservasi," Indones. J. Conserv., vol. 3, no. 1, 2014.

[37] Y. D. Ariyani and M. N. Wangid, "Pengembangan Bahan Ajar Tematik-Integratif Berbasis Nilai Karakter Peduli Lingkungan dan Tanggung Jawab," J. Pendidik. Karakter, no. 1, 2016.

[38] S. Soeprijanto and G. Femalia, "Evaluation of nature school in Indonesia using illuminative evaluation model," in AIP Conference Proceedings, 2018, vol. 2019, no. 1, p. 30005. 